\title{
The impact of political parties on the distribution of state and local tax burdens
}

\author{
Christopher Dennis ${ }^{\mathrm{a}, *}$, William S. Moore ${ }^{\mathrm{b}}$, Tracey Somerville ${ }^{\mathrm{a}}$ \\ ${ }^{a}$ Department of Political Science, California State University at Long Beach, \\ Long Beach, CA 90840, United States \\ ${ }^{\mathrm{b}}$ Graduate Center for Public Policy and Administration, California State University at Long Beach, \\ Long Beach, CA 90840, United States
}

\begin{abstract}
Using a disaggregated measure that allows us to examine the distribution of state and local tax burdens between high and low income groups better, this research finds that in many models, Democratic control is positively associated with a lower relative tax burden on the poor. The results are stronger for average Democratic strength in the state government than for unified Democratic strength. The results are strongest when comparing income groups just below the richest $1 \%$ (the next richest $2-5 \%$ and the next richest $6-20 \%$ ) with the poorest $20 \%$.

Income inequality is strongly negatively associated with the degree of state and local tax progressivity. (C) 2007 Elsevier Inc. All rights reserved.
\end{abstract}

\section{Background}

Increasing income inequality is one of the foremost issues confronting governments in the United States. During the 1979-2000 period, the average after-tax income of the wealthiest $1 \%$ of the population increased by $201 \%$, while the corresponding figures for the middle fifth and bottom fifth were 15\% and 9\% (Greenstein \& Shapiro, 2003; for the increased concentration within the highest $1 \%$ see Piketty \& Saez, 2003). These differing growth rates of after-tax income resulted, economically, in a country that is less egalitarian.

While many factors impact the level of income inequality, relative state and local tax burdens alter the after-tax distribution of income in the United States. States vary noticeably in the

* Corresponding author. Tel.: +1 5625977287.

E-mail addresses: cdennis@csulb.edu (C. Dennis),wmoore2@csulb.edu (W.S. Moore), tsomervi@csulb.edu (T. Somerville). 
relative tax burdens they place on citizens. For example, in the most progressive state, Delaware, state and local taxes represented $7.6 \%$ of income for the wealthiest $1 \%$ of non-elderly married couples while only $6.3 \%$ of income for the poorest $20 \%$ of non-elderly married couples (i.e., a ratio of 1.2). However, for the least progressive state, Nevada, the corresponding figures where $1.8 \%$ and $8.9 \%$ (i.e., a ratio of only .2 ). ${ }^{1}$

This is the first paper to analyze the impact of political variables on the distribution of state and local tax burdens at the extremes of the income distribution (i.e., the poorest $20 \%$ vs. the richest $1 \%$, percentiles $2-5$ and percentiles $6-20$ ), as opposed to either the entire income distribution, or a large group on both the top and the bottom. As the findings of this study will show, disaggregating the high-income group changes the findings concerning the impact of political parties on economic inequality.

Previous research suggests a number of potential explanations for disparities in relative state tax burdens between high and low income families. Political variables have frequently been linked to public policies and economic outcomes. Hibbs (1987) and Bartels (2002) find that Democratic control of the presidency and Congress is associated with a greater relative share of income going to the poorest $40 \%$ of American families. Moreover, at the state level, Erikson, Wright, and McGiver (1993, pp. 168-173) find that greater Democratic strength in the legislature is associated with more liberal policies. Since unified party control may be the appropriate measure of political "control" this alternative will also be explored. Studies of public opinion find that more liberal state electorates are associated with more liberal state policies (Erikson et al., 1993, pp. 168-173; Radcliff \& Saiz, 1998). Additionally, the degree of political competition between parties may also impact the progressivity of state tax burdens. Lowery (1987), Morgan (1994) and Radcliff and Saiz (1998) find that greater electoral competition is associated with more progressive state and local tax burdens. Another political variable that might impact the distribution of state and local tax burdens over income classes is the class composition of the electorate. The greater the relative electoral strength of the poor, the lower the likely relative tax burden on the poor. A final political variable that could impact the distribution of state and local tax burdens are interest groups. Radcliff and Saiz (1998) find that union strength is positively associated with shifting state and local tax burdens more toward the affluent. Since the impact of both Democratic governmental and union strength could also be affected by the class composition of the electorate, it seems appropriate to test Democratic strength, union strength, and the class composition of the electorate both additively and interactively.

While politics may influence the distribution of relative tax burdens, economic factors may also be important. Both Lowery (1987) and Radcliff and Saiz (1998) find the greater the relative size of business in a state, the more progressive the state and local tax burden. An additional economic factor that could influence the distribution of the tax burden is the degree of income inequality. The greater the degree of income inequality, the fewer political resources the poor will have and the less progressive state and local taxes are likely to be. The rate of income growth could also influence demand for tax progressivity.

The greater the rate that income is increasing, the more generous people may feel, and the greater the degree of redistribution through the tax system. Lowery (1987, p. 148) finds that it is change in the level of median family income, as opposed the absolute level of median family income that is related to the progressivity of state and local tax burdens. ${ }^{2}$ 
As public policy at any given time is likely to be a function, in part, of policies from previous time periods, it seems reasonable to include prior tax policies as independent variables. As Radcliff and Saiz (1998, p. 118) note, “... states that adopted broad-based taxes (i.e., on income or retail sales) early on tend to have more progressive tax codes than states that did not." The models we test will utilize all of the independent variables mentioned thus far.

\section{Data, measures and methods}

The dependent variable is the ratio of state and local taxes (sales and excise, property and personal and corporate income taxes) as a percentage of income of a wealthy group (either the richest $1 \%$, percentiles $2-5$ or percentiles 6-20), of non-elderly married couples to the corresponding percentage for the poorest $20 \%$ of non-elderly married couples. The data are from The Citizens for Tax Justice for 1995. The higher the score (i.e., ratio), the more progressive the non-federal tax burdens in a state. Data for non-married individuals and the elderly are not available. No other dataset contains estimates of the distribution of state and local tax burdens for the income groups used in this study (i.e., the wealthiest $1 \%$, 2nd-5th percentile, etc.).

Current public policy options are often constrained by previous policies. Thus, regardless of how liberal or conservative the current state government, politically feasible policy options may be limited by the actions of previous state governments. This is why Lowery (1987) used Democratic party strength over a 17-year period (1960-1976) to explain inequality in state and local tax burdens at one time point (1976). Following Lowery (1987), the first independent variable is average Democratic strength in the state over the 1980-1995 period. The measure is a percentage calculated by treating the governor and the legislature equally (i.e., both are $50 \%$ of Democratic strength in the state government). Both chambers of the legislature are also treated equally (i.e., each chamber is worth $25 \%$ of total Democratic strength in the state government). ${ }^{3}$ Since political control, as opposed to average political strength may be preferable, this study also uses a measure of the proportion of years during the 1980-1995 period a state was governed by unified Democratic control. Additionally an interaction term composed of average Democratic strength, union strength, and Hill and Leighley's (1992) measure of the relative voting strength of families with incomes of $\$ 50,000$ and above to families with incomes of $\$ 12,500$ or less times 100 is also employed in some of the analyses. Finally, an interaction term with the proportion of times the state was governed by unified Democratic control replacing average Democratic strength is also utilized.

The other independent variables are as follows: liberalism of the electorate is measured by Erikson et al. (1993, p. 16) mean state ideology; political competition is measured by Holbrook and Van Dunk's (1993) measure of electoral competition; union strength is operationalized as the percentage of those employed in a state who are members of a labor union in 1993 (Hirsch \& Macpherson, 1994); electoral strength of the wealthy is Hill and Leighley's (1992) measure of the relative voting strength of families with incomes of $\$ 50,000$ and above to families with incomes of $\$ 12,500$ or less times 100 ; size of business is measured by taking the value added from manufacturing as a percentage of gross state product in 1992 (State and Metropolitan Data Book: 1997-19984; gross state product is from the U.S. Department of 
Commerce's Regional Economic Information System); change in median household income is the proportional change in median household income over the 1985-1995 period (U.S. Census Bureau's Historical Income Tables); state income and sales tax history (whether a state had one, or both, in 1976) is taken from Phares (1980); and income inequality is Langer's (1999) Gini coefficient for each state in 1989.

From a research design standpoint, separate controls for the presence of a state income and/or sales tax almost 20 years prior to the distribution of the state and local tax burden are very important. State tax policy at one point in time is likely to be constrained by previous policy decisions. Politically, it is easier to alter an existing tax than to add a new tax (Hansen, 1983). By including variables for the presence of state income and sales taxes prior to the period of the political variables, this study provides important controls for the state tax policy climate each legislature inherited from the time prior to the period of study. While optimal, time series data on the distribution of the state and local tax burden over the income groups this study examines have never been collected.

\section{Findings}

In order to save space it should be noted that the results for five independent variables were never statistically significant in any equation (public liberalism, electoral competition, unionization, manufacturing and change in the median family income) are not shown. ${ }^{5}$ Columns 1 and 2 of Table 1 show the results for the additive model previously discussed. Because of the large impact of the income tax variable, columns 3 and 4 replicate the analysis of columns 1 and 2 except that only the 45 states having an income tax are examined. It should be noted that state income tax history is virtually constant since 1976 (only Alaska, which dropped the income tax, either added or deleted the income tax over the 1976-1995 period). Columns 5 and 6 provide the results for the interactive model between the two measures of Democratic control, liberal organizational strength (union) and the class composition of the electorate. The analysis is of the 45 states having an income tax. Tables 2 and 3 are the same except that the high income category changes from the top $1 \%$ to the 2 nd through 5 th percentiles (Table 2) and the 6th through 20th percentiles (Table 3).

\section{Discussion}

Average Democratic strength is signed as hypothesized and statistically significant in seven of the nine equations it appears. By contrast, unified Democratic strength is never statistically significant. This is different from the negative findings of Lowery (1987), Morgan (1994) and Radcliff and Saiz (1998). Moreover, the impact of average Democratic strength is additive, not interactive. Importantly, the impact of average Democratic strength is greater once we move from the richest $1 \%$ to those just below the richest $1 \%$ but still within the richest $20 \%$. It should be noted that average Democratic strength, not the frequency of a Democratic governor in office, is critical. ${ }^{6}$ The results of this research suggest that the state political parties differ more on distributional outcomes between the rich (those from the 2 nd through 20 th percentiles) and 
Table 1

The impact of political and economic variables on the distribution of state and local tax burdens between the richest $1 \%$ and the poorest $20 \%$ of non-elderly married couples

\begin{tabular}{|c|c|c|c|c|c|c|}
\hline & (1) & (2) & (3) & (4) & (5) & (6) \\
\hline Constant & $.616(.75)$ & $.699(.83)$ & $1.361(1.45)$ & $1.256(1.28)$ & $1.350(1.41)$ & $1.139(1.15)$ \\
\hline Average Democratic strength & $.003(1.35)$ & & $.004 *(1.74)$ & & $.004(1.61)$ & \\
\hline Unified Democratic control & & $.060(.52)$ & & $.060(.46)$ & & $.318(1.03)$ \\
\hline Average Democratic interaction & & & & & $.000(.16)$ & \\
\hline Unified Democratic interaction & & & & & & $-.000(-.92)$ \\
\hline Class polarization & $.001(1.31)$ & $.002 *(1.70)$ & $.002(1.46)$ & $.002 *(1.78)$ & $.002(1.43)$ & $.003 *(1.99)$ \\
\hline Income inequality & $-1.982(-.98)$ & $-1.858(-.89)$ & $-3.099(-1.30)$ & $-2.163(-.89)$ & $-3.048(-1.25)$ & $-2.264(-.93)$ \\
\hline Income tax & $.489 * * *(4.73)$ & $.511 * * *(4.89)$ & & & & \\
\hline Sales tax & $-.173(-1.50)$ & $-.136(-1.19)$ & $-.161(-1.33)$ & $-.116(-.91)$ & $-.164(-1.31)$ & $-.107(-.84)$ \\
\hline Adjusted $R^{2}$ & .44 & .41 & .12 & .03 & .09 & .03 \\
\hline
\end{tabular}

Estimated $t$ statistics in parentheses. * $p<.10 ; * * p<.05 ; * * * p<.01$. 
Table 2

The impact of political and economic variables on the distribution of state and local tax burdens between the 2nd and 5th percentiles and the poorest $20 \%$ of non-elderly married couples

\begin{tabular}{|c|c|c|c|c|c|c|}
\hline & (1) & (2) & (3) & (4) & (5) & (6) \\
\hline Constant & $.808(1.28)$ & $.925(1.42)$ & $1.585 * *(2.23)$ & $1.498 *(1.98)$ & $1.581 * *(2.18)$ & $1.434 *(1.86)$ \\
\hline Average Democratic strength & $.003 *(1.74)$ & & $.004 * *(2.41)$ & & $.004 * *(2.27)$ & \\
\hline Unified Democratic control & & $.109(1.20)$ & & $.117(1.14)$ & & $.258(1.07)$ \\
\hline Average Democratic interaction & & & & & $.000(.08)$ & \\
\hline Unified Democratic interaction & & & & & & $-.000(-.07)$ \\
\hline Class polarization & $.001(1.19)$ & $.001(1.54)$ & $.001(1.41)$ & $.001 *(1.69)$ & $.001(1.39)$ & $.002 *(1.80)$ \\
\hline Income inequality & $-2.118(-1.35)$ & $-2.111(-1.31)$ & $-3.544 *(-1.97)$ & $-2.680(-1.43)$ & $-3.525 *(-1.91)$ & $-2.735(-1.45)$ \\
\hline Income tax & $.398 * * *(4.97)$ & $.413^{* * *}(5.10)$ & & & & \\
\hline Sales tax & $-.143(-1.60)$ & $-.118(-1.33)$ & $-.133(-1.45)$ & $-.100(-1.02)$ & $-.134(-1.42)$ & $-.095(-.96)$ \\
\hline Adjusted $R^{2}$ & .48 & .46 & .18 & .07 & .15 & .05 \\
\hline
\end{tabular}

Estimated $t$ statistics in parentheses. $* p<.10$; ** $p<.05 ; * * * p<.01$. 
Table 3

The impact of political and economic variables on the distribution of state and local tax burdens between the 6th and 20 th percentiles and the poorest $20 \%$ of non-elderly married couples

\begin{tabular}{|c|c|c|c|c|c|c|}
\hline & (1) & (2) & (3) & (4) & $(5)$ & (6) \\
\hline Constant & $1.146 *(1.91)$ & $1.273 * *(2.06)$ & $1.898 * * *(2.88)$ & $1.807 * *(2.52)$ & $1.894 * *(2.82)$ & $1.763 * *(2.41)$ \\
\hline Average Democratic strength & $.003 *(1.95)$ & & $.005 * * *(2.79)$ & & $.005 * *(2.64)$ & \\
\hline Unified Democratic control & & $.118(1.37)$ & & $.131(1.36)$ & & $.227(.99)$ \\
\hline Average Democratic interaction & & & & & $.000(.07)$ & \\
\hline Unified Democratic interaction & & & & & & $-.000(-.46)$ \\
\hline Class polarization & $.000(.89)$ & $.001(1.27)$ & $.001(1.21)$ & $.001(1.52)$ & $.001(1.19)$ & $.001(1.56)$ \\
\hline Income inequality & $-2.604 *(-1.75)$ & $-2.604(-1.70)$ & $-4.103 * *(-2.47)$ & $-3.187 *(-1.81)$ & $-4.086 * *(-2.39)$ & $-3.225^{*}(-1.80)$ \\
\hline Income tax & $.358 * * *(4.72)$ & $.373 * * *(4.886)$ & & & & \\
\hline Sales tax & $-.137 *(-1.62)$ & $-.112(-1.32)$ & $-.131(-1.54)$ & $-.097(-1.05)$ & $-.132(-1.51)$ & $-.094(-1.00)$ \\
\hline Adjusted $R^{2}$ & .47 & .44 & .21 & .07 & .19 & .04 \\
\hline
\end{tabular}

Estimated $t$ statistics in parentheses. * $p<.10 ; * * p<.05 ; * * * p<.01$. 
the poor, as opposed to the very rich (those in the highest percentile) and the poor. By focusing on particular income groups within the richest $20 \%$ of households, this study has found that the impact of partisan political control of state government on the distribution of the state and local tax burden matters.

There are at least three possible reasons for this. First, due to the great reliance by candidates on campaign contributions from very wealthy individuals, neither party may want to pursue economic policies that seriously erode either the relative or absolute position of the very rich (Ferguson, 1995). Second, state officials may believe that if state taxes were extremely progressive the wealthy would move to other states. Finally, elites in both parties may believe that the requirements of a capitalist system require a very affluent group at the top.

Not surprisingly, the presence of an income tax has a large impact on the progressivity of state and local tax burdens. It is signed as hypothesized and easily statistically significant in all six equations it appears. However, even if we restrict the analysis to states having an income tax, Democratic strength is often statistically significantly related to the progressivity of state and local tax burdens. By contrast, the presence of a state sales tax is statistically significant in only 1 of the 18 equations.

The results of this research also indicate that income inequality matters: greater income inequality is associated with a less progressive state and local tax structure. Income inequality is always signed as hypothesized and often statistically significant. These findings are particularly important since income inequality in the United States has increased noticeably since the time period of the data used in this study (Greenstein \& Shapiro, 2003; Piketty \& Saez, 2003). However, while only significant in 5 of the 18 equations, the findings concerning the impact of class polarization of the electorate are counter-intuitive: the greater participation favors the affluent the more progressive the distribution of state and local tax burdens. The reasons for this are unclear.

The findings of this study reinforce why we need to look at disaggregated, as well as aggregated measures. Sometimes there is an interesting story that is concealed by more aggregated data.

\section{Notes}

1. See Anonymous (1996): Who Pays? A Distributional Analysis of the Tax Systems in All 50 States. The mean ratio of state and local taxes as a percentage of income for the wealthiest $1 \%$ of non-elderly households to the poorest $20 \%$ of non-elderly households was .656 while the standard deviation was .239.

2. Replacing the change in median household income with the absolute level of household income has virtually no impact on the findings. Since we are using data over an extended time period to explain something at a later time period, theoretically, change in the level of household income is more appropriate than the absolute level of household income.

3. The authors would like to thank Robert Lowery for supplying this data. He took the data from various editions of the Book of the States.

4. An alternative size of business measure was also employed: private industry state gross product divided by total state gross product. This alternative measure does not change the results in any meaningful way. 
5. Results for models using all independent variables are available from Christopher Dennis. If you rerun the analysis with only the independent variables that appear in Tables 1-3, the only changes of note are that income inequality becomes more significant and unified Democratic control is significant in two of the nine equations it appears. Additionally, adding a North/South dummy variable does not noticeably alter the findings.

6. If average Democratic strength is replaced with the percentage of times the state had a Democratic governor over the 1980-1995 period, the Democratic gubernatorial variable is only significant in one of the nine equations.

\section{References}

Anonymous. (1996). Who pays? A distributional analysis of the tax systems in all 50 states. Washington, D.C.: Citizens for Tax Justice and the Institute on Taxation and Economic Policy.

Bartels, L. M. (2002). Partisan politics and the U.S. income distribution, 1948-2000, mimeo. In Book of the states. Lexington, Kentucky: Council of State Governments.

Erikson, R. S., Wright, G. C., \& McIver, J. P. (1993). Statehouse democracy. Cambridge, UK: Cambridge University Press.

Ferguson, T. (1995). Golden rule. Chicago: University of Chicago Press.

Greenstein, R., \& Shapiro, I. (2003). The new, definitive cbo data on income and tax trends, mimeo. Center on Budget and Policy Priorities. http://www.cbpp.org

Hansen, S. B. (1983). The Politics of taxation: revenue without representation. New York: Praeger.

Hibbs, D. A. (1987). The American political economy. Cambridge: Harvard University Press.

Hill, K. Q., \& Leighley, J. E. (1992). The policy consequences of class bias in state electorates. American Journal of Political Science, 36, 351-365.

Hirsch, B., \& Macpherson, D. (1994). Union membership and earnings data book 1993: Compilations from the current population survey. Washington: Bureau of National Affairs.

Holbrook, T., \& Van Dunk, E. (1993). Electoral competition in the American states. American Political Science Review, 87, 955-962.

Langer, L. (1999). Measuring income distribution across space and time in the American states. Social Science Quarterly, 80, 55-67.

Lowery, D. (1987). The distribution of tax burdens in the American states. Western Political Quarterly, 40, 137158.

Morgan, D. R. (1994). Tax equity in the American states: A multivariate analysis. Social Science Quarterly, 75 , 510-523.

Phares, D. (1980). Who pays state and local taxes. Cambridge: Oelgeschlager, Gunn and Hain.

Piketty, T., \& Saez, E. (2003). Income inequality in the United States, 1913-1998. Quarterly Journal of Economics, $118,1-39$.

Radcliff, B., \& Saiz, M. (1998). Labor organization and public policy in the American states. Journal of Politics, $60,113-125$.

U.S. Census Bureau. (1984-2000). Table h-8: Median household income by state. http://www.census.gov/hhes/ income/histinc/h08.html.

U.S. Department of Commerce. (1998). State and metropolitan area data book. Washington, D.C.: U.S. Government Printing Office. 